\title{
POLITICAL INFLUENCE ON THE CONSTITUTIONAL COURT IN THE REPUBLIC OF MACEDONIA: REFLECTIONS THROUGH THE DISSENTING OPINIONS IN THE PERIOD OF 2012-2015
}

\author{
Sonja Stojadinovic \\ Independent Researcher \\ sonja.stojadinovic@gmail.com
}

\begin{abstract}
The demo Christian political party VMRO-DPMNE had a long period of ruling of the Republic of Macedonia, (2006-2016). During that period many cases of political pressure on the state institutions have occurred. The Constitutional Court wasn't an excepted of that political pressure. Starting from the process of appointment of new judges, through the shocking decisions upon official citizens' complaints and human rights appeals, to a complete reflection of the political interference and pressure through the dissenting opinions written and published by some constitutional judges. The former government has used all the tools, legal and non-legal, to put under control the Constitutional Court. If we put aside the political interference into the appointment of new and incompetent judges, one of the most used tools as a form of resistance was the dissenting opinion. This legal tool is present in the Book of Rules of the Constitutional Court of the Republic of Macedonia, but also in the legal systems in the Eastern Europe, Germany, Spain, Greece and all other states whose legal systems are created by the German legal system. It gives space and chance for one or several constitutional judges to express disagreement upon a decision brought by the majority in the court. This tool was frequently used by several judges from the Constitutional Court in the Republic Macedonia in the given period through which we can see strong political influence on their work. Therefore, the research questions are as follows: What were the "models" of political influence that were used on the Constitutional Court during the period of 2012-2015? How were they used

* Sonja Stojadinovic holds bachelor and master degrees in political science and international relations, both obtained on the Faculty of Law, Skopje, University of st. Cyril and Methodius, Republic of North Macedonia. Her professional and research experience covers subjects of European Union integration process, international relations, labor law, workers' rights, social equality.
\end{abstract}


and what are the dissenting opinions reflecting? To answer the said questions, the model of qualitative research will be used together with several dissenting opinions as case studies. The aim of this approach is to explain the different aspects of political influence on the work of the Constitutional Court within the given period. The findings of this research can be used for further development of the interest for researching of the work and role of the Constitutional Court in the Republic of Macedonia.

Keywords: Political Influence, Dissenting Opinion, Misconduct, Constitutional Court, Judges.

\section{INTRODUCTION}

Within the period of 2006-2016, Republic of Macedonia was ruled by the conservative demo Christian political party VMRO-DPMNE in coalition with the Albanian party DUI (Democratic Union for Integration). This period of ruling was marked by complete political divide and politicization of the whole state system, a state classified by the High European Union commissioners as state capture, "Democracy and rule of law have been constantly challenged, in particular due to state capture affecting the functioning of democratic institutions and key areas of society."

The whole state system functioned with high level of political corruption followed by realization of private business interest through political decisions. Implementation of the state policies went through stake holders and companies whose owners were already established politicians, members of the ruling coalition.

The political influence and interference within the state institutions was highly present. The Constitutional Court, seen by the citizens as the last bastion of justice, was not spared from political pressure and influence by the governmental coalition as the mandate of the judges previously elected was expiring and new ones were appointed. This was obvious in the process of appointing new judges, who were of low quality or had already proven their political affiliation through their decisions, which they had adopted at their previous work positions and were

\footnotetext{
"Commission Staff Working Document," European Commission, 2016, 4, accessed 10 August 2018, https:// ec.europa.eu/neighbourhood-enlargement/sites/near/files/pdf/key_documents/2016/20161109_report_the_former_ yugoslav_republic_of_macedonia.pdf.
} 
in favor of the ruling political party. Some processes of appointing new judges were unpredictable. Such was the example of appointing a judge for the position of president of the Constitutional Court who was already retired and who had flagrant family attachment to the ruling party (Elena Gosheva). The period of her presidency of the court was marked by her unprofessional behavior towards her colleagues and journalists and she was known for prohibition of presence of the media during certain court sessions important for the public interest. ${ }^{2}$ One of the controversial decisions that were brought by the Constitutional court was the start of a procedure for assessment of the constitutionality on the Pardon Law in March 2016. In spite of the reactions and warnings by the civil and academy sectors, the Constitutional Court repealed the amendments on the Pardon Law from 2009 which were published on the Akademik's web site $^{3}$. With this repeal, the Court has allowed the president to pardon convicts for criminal activities in election processes, drug dealers, pedophilia but above all the high officials of the then ruling VMRO DPMNE who were accused of series of crimes and corruption cases by the Special Public Prosecutor followed on the Akademik's website. ${ }^{4}$

The policy implemented by the governmental coalition led by VMRO-DPMNE was false and it was a product of personal and business interests. The reports by the European Union Commission on within the enlargement policy for year of 2016 have declared Republic of Macedonia as politically captured state which is clearly showing how the personal interests of the politicians have influenced public policies. ${ }^{5}$ This situation pushed the citizens to start using legal tools to initiate procedures for assessment of the constitutionality of governmental decisions and articles of laws in front of the Constitutional Court. This legal

\footnotetext{
Gordana Duvnjak, "Уставен суд нова фаза [Constitutional Court new phase]," link last active 30.04.2017, utrinski. com.mk.

3 Marija Sevrieva, "Уставниот суд ги укина измените на законот за помилување [The Constitutional Court have abolished the amendments on the Law on abolition]," accessed 10 August 2018, https://www.akademik. mk/ustavniot-sud-gi-ukina-izmenite-na-zakonot-za-pomiluvanje-so-nego-se-ogranichuvalo-ustavnoto-pravo-napretsedatelot-na-rm/.

4 Marija Sevrieva, "Објавени помилувањата [The abolition are published]," accessed 10 August 2018, https:// www.akademik.mk/objaveni-pomiluvanjata-gruevski-mijalkov-crvenkovski-obviniteli-vo-sjo/.

5 "Commission Staff Working Document," European Commission, 2016, accessed 10 August 2018, https://ec.europa. eu/neighbourhood-enlargement/sites/near/files/pdf/key_documents/2016/20161109_report_the_former_yugoslav_ republic_of_macedonia.pdf.
} 
tool offers a chance for common citizens to challenge the policies of the current or the previous governments. Also, the Article 25 from the Rule of Procedure of the Constitutional Court allows expression of different opinion by one or several judges whose standpoint is not in line with the majority of the votes. ${ }^{6}$ This tool is the dissenting opinion and is a qualitative legal matter through which a certain governmental policy can be evaluated. One of the most persistent judges who followed the "letter of the law" and used the tool of dissenting opinion very often, was the now former Constitutional judge Natasha Gaber Damjanovska whose mandate has expired in October 2017.7 She was known to be one of the few judges from this court who were seen in the public sphere as true protectors of the Constitution. After the end of her 9-year-mandate in the court, she has published a book with selected dissenting opinions clearly drawing the political situation in the given period of 2012-2015. Through the dissenting opinions on the amendments of the Law on Abortion, Law on Civic Responsibility of Insult and Slander, articles of the, Law on Determination of Condition for Limitation on Performing Public Function, Access to Documents and Publications of Cooperation with the Authorities of State Security, the negative implications of the false state policy implemented by the government of VMRO-DPMNE can easily be located.

Therefore, the aim of the research question is to uncover the models of the political influence on the Constitutional Court and how the political influences have been reflected on the decisions of the Court through the dissenting opinions in the given period. In order to answer the given questions, the model of qualitative research will be used, together with analyses of three dissenting opinions on Constitutional Court decisions which had the most reactions in the public.

6 Article 25 from the Rule Book of the Constitutional Court: A judge who voted against the decision or believes that it should be based on other legal grounds may set aside his opinion and elaborate in writing. The dissenting opinion shall be published in the "Bulletin of the Court" and in the official journal in which the decision of the Court is published.

7 "Short Biography of Dr. Natasha Gaber-Damjanovska," Website of The Constitutional Court of the Republic of Macedonia, accessed 11 August 2018, goo.gl/5cm1jo. 


\section{DISSENTING OPINION AS A LEGAL TOOL}

The first tracks of existence of dissenting opinion have been noted in the $15^{\text {th }}$ century in Spain under the name of voto reservado, which is a form of expression of judges' disagreement written in a secret, unpublished book. ${ }^{8}$ This practice has been preserved in the Spanish judicial system until 1985 when the use of dissenting opinion was expanded into the whole judicial system. Despite on these early signs of existence of the dissenting opinion, the first state that has implemented this legal tool into the system of the constitutional courts is Germany. In 1952 the Federal Constitutional Court in Western Germany allowed publication of anonymous dissenting opinions. The next following this upgrade of the judicial system were Greece and Portugal who allowed the use of dissenting opinion within their Constitutional courts. The Portuguese legal system allowed for the judges to add the term vencido next to their signature on a court's decision, expressing their disagreement. ${ }^{9}$ Later, in 1982, when the Constitutional Court was established, publishing of dissenting opinions was introduced into the practice of the Court. The system in Greece, for example, is the common law type. Although the publishing of dissenting opinions is compulsory, the practice to keep them anonymous, has remained. ${ }^{10}$ Contrary to this examples, the Constitutional Courts in Italy, France and Belgium do not offer the possibility for the judges to write and publish their dissenting opinions.

In comparison to the above-mentioned European states, the situation in Central and Eastern Europe is little different. All Constitutional Courts are allowing publication of dissenting opinions. In Slovenia, opinions are published on the web site of the court because publishing in the Official Gazette has to be paid. Dissenting opinion of the judges from the Constitutional Court in the Republic of Macedonia are also published on the web page of the court. One question arises from this brief comparison of Constitutional Courts in Eastern

\footnotetext{
8 Chapter XIV of the Ordenanzas de Medina, in Novíssima r ecompilación de las leyes de España,Tomo II, Boletín Oficial del Estado 350 (1976) [Chapter XIV of the Ordinances of Medina, in New compilation of the Laws of Spain, Volume II, Official Gazette of the State 350 (1976)]. accessed 12 July 2018, http://pares.mcu.es/ParesBusquedas20/ catalogo/description/184080.

9 Katalin Kelemen, "Dissenting opinions in Constitutional Courts," German Law Journal 14, no.08 (2013).

10 Ibid.
} 
and Western Europe. Jullia Laffranque ${ }^{11}$ claims that the freedom to write and publish dissenting opinion as a Constitutional judge is important in states where the legal culture is not fully developed yet, like are the countries from Central and Eastern Europe. Additionally, constitutional law is more affected by political regimes than by other branches of the law. That is one of the reasons why the dissenting opinion as a legal tool is so important for the independence of the work of the Constitutional Court.

There is only one fact which is not in favor of the constitutional courts and their importance to the legal system. Apart from the Austrian Constitutional Court which was established in 1920 by the model of the legal theorist Hans Kelsen, all other constitutional courts in Europe are established after the Second World War. ${ }^{12}$ In comparison to the influence of the Supreme Court, the Constitutional Court was forced to build authority and legitimacy through its work from the very beginning. The dissenting opinion is a tool which guarantees transparency that is of huge importance for the strong role of the constitutional court. Even in Germany, on which structure the legal systems of several other legal systems rely, specially from the Central and Eastern Europe, needed almost 20 years to establish full transparency of the tool of dissenting opinion. On the other hand, the fact that goes in favor of the Constitutional Courts is that their sui generis nature is created with the right on dissenting opinion. By the nature of their work, constitutional judges use different interpretation techniques and are less bind by the traditional style of argumentation. ${ }^{3}$

Regardless of how much the public opinion is in favor of dissenting opinions by constitutional judges, in order to have more access to the work of the court, two principles that are little complicated to handle arise. The question of whether or not judicial independence and transparency of the decision making process can be influenced by dissenting opinion is a subject dealt by academic debate.

${ }_{11}$ Julia Laffranque, "Dissenting Opinion in the European Court of Justice. Estonia's Possible Contribution to the Democratisation of the European Union Juridical System," Juridica International 14 (2004).

12 Federico Fabbrini, "France's Constitutional Reform and the Introduction of a Posteriori Constitutional Review of Legislation," German Law Journal 9, no.10 (2008): 1297.

13 Andras Jakab, "Judicial reasoning in Constitutional Court - A European perspective" German Law Journal 2, no. 29 (2013): 1215-1278. 
The answer is, yes, it does have influence, especially when it comes to the possibility of economic or political pressure on one or several judges that have published their dissenting opinions. The case is similar when it comes to the possibility of re-election of judges. The dissenting opinion can be used for gaining popularity in the public by the judge whose aim is to be re-elected. In order to avoid this kind of pressures on judges when it comes to re-election and possible misuse of the dissenting opinion tool, the Venice Commission has recommended prohibition of its use during re-elections. ${ }^{14}$

On the other hand, when it comes to expressing judicial independence, this is highly used tool by judges to practice the freedom of expression. One of the most impressive practice of the dissenting opinion tool is the publishing of all of the dissenting opinions by the Hungarian Constitutional judge Imre Voros. "Dixi et salvavi animam meam" which means "I spoke, and I saved my soul". Even though the dissenting opinion is not legally binding, its presence is remarkably useful tool for future generations of researchers of the constitutional law and courts and the descending judges. ${ }^{15}$

Within the U.S. Supreme Court, for example, voting is public, which is not the case in most of the European Constitutional Courts. The dissenting opinion tool provides information on how certain judges voted based on their published opinion. As a legal tool, dissenting opinion offers valuable insight on how constitutional courts work. ${ }^{16}$

\section{SHORT HISTORY OF THE MACEDONIAN CONSTITUTIONAL COURT}

In the period of 1945 to 1991, Republic of Macedonia was a socialist republic within the federation of the Socialist Federal Republic of Yugoslavia. The Constitutional Following the development of the judicial system in Europe, the

\footnotetext{
4 "The Composition of Constitutional Courts, in Science and Technique of Democracy No.2opt.4.2," Venice Commission, 1997, http://www.venice.coe.int/webforms/documents/CDL-STD(1997)020.aspx. Accessed 02.08.2018.

15 Imre Vörös, Dixi et salvavi. Különvélemények, Párhuzamos Indokolások [Dixi et salvavi. Dissenting and concurring opinions] (2000).

16 David Lazarus, "The Supreme Court's Excessive Secrecy: Why It Isn't Merited," Find Law Legal News, Sept. 30,2004, accessed 2 August 2018, http://writ.news.findlaw.com/lazarus/20040930.html.
} 
Constitutional Court in the Socialist Republic of Macedonia was established in 1964. Its position and competence were governed by the Constitution, and the procedure and the legal effect of its decisions were governed by the Law on the Constitutional Court of Macedonia from 1963. In 1991, the Republic of Macedonia became independent state and the Constitutional Court continued with its work in the newly founded state. ${ }^{17}$

The work of the Constitutional Court is governed by Articles 108 to 113 of the Constitution. The competences of the Macedonian Constitutional Court are as follows: control of constitutionality and legality, protection of freedoms and rights of the individual and citizen, resolution of conflicts of jurisdiction, deciding on the responsibility of the President of the republic, deciding upon constitutionality of the programs and statues of the political parties and civil organizations. ${ }^{18}$ The court has 9 judges with mandate of 9 years, without possibility of re-election. Constitutional judges are proposed by the Parliament (5), the President (2) and the Judicial Council (2). ${ }^{19}$ One of the differences in the work of the Constitutional Court from the period when Republic of Macedonia was federal unit within Yugoslavia is that the work of the Court is regulated by the articles of the Constitution, the Rules of Procedure brought by the Court itself and the Rule book for work. The Law on the Constitutional Court that existed in the period of Yugoslavia is abolished. One of the states that is successor of Yugoslavia and still has a Law on the Constitutional Court is Serbia. ${ }^{20}$

When it comes to the right of constitutional judge to write a dissenting opinion, this is regulated by Article 25 of the Rules of Procedure of the Court: "A judge who has voted against the decision or believes that it should be based on other legal grounds may set aside his opinion and elaborate in writing. The dissenting opinion shall be published in the "Bulletin of the Court" and in the official journal in which the decision of the Court is published." ${ }^{21}$

\footnotetext{
Macedonian Constitutional Court, short history (official page), ustavensud.mk Accessed 05.08.2018 8 lbid.

19 "Macedonian Constitutional Court (official page)," ustavensud.mk, Accessed 5 August 2018.

20 "Serbian Constitutional Court," http://www.ustavni.sud.rs/ Accessed 05.08.2018.

${ }^{21}$ Ibid.
} 


\subsection{Disadvantages of the Functioning of the Constitutional Court}

When it comes to the procedure for voting for new judges, the Parliament has the right to candidate the majority of judges, five from nine from the whole number of judges from the Court. This condition leaves big space for political pressure and appointing judges which are affiliated to the ruling political party. Since the independence of the state. the situation was used countless of times by all political parties who were in the government, which had the majority in the Parliament and influenced on the reputation of the judges and the Constitutional Court. In addition, the voting for new constitutional judges needs only simple majority of the votes in the Parliament. In this case, Denis Preshova argues and gives his suggestion for change of the voting system and decrease of the political influence on the constitutional judges ${ }^{22}$ He suggests that it is much better for Macedonia to adopt the Hungarian model, according to which all political parties from the Parliament have to have equal number of representatives in the Parliamentary Commission that creates the list of candidates. In continuance, judges will be elected in the Parliament by two thirds of the majority. This model will force political parties on both sides (ruling and the opposition) to cooperate more in order to elect judges with higher quality.

The following instance raising eyebrow is the only condition for one to be elected as a constitutional judge. Article 109 of the Constitution states: 'The judges of the Constitutional Court are elected from among distinguished lawyers.' What are the standards for a candidate to be regarded as a distinguished lawyer and who establishes them? Who sets the rules? This is another condition allowing space for personal and political interpretation of the term "distinguished lawyer" and it always goes in favor and interest of the political parties. In search for maybe not the best but better solution of this loophole, we can take the solution from the Constitutional Court and the Law on the Constitutional Court in Croatia as an example. The Law says: A judge of judges may be selected from among distinguished lawyers especially from the ranks of judges, public prosecutors,

\footnotetext{
Denis Preshova, Реформи на Уставниот суд или реформа на свеста?Реформа на институциите и нејзиното значење за развој на Република Македонија [Reforms of the Constitutional Court or reforms of consciousness? Reform of the institutions and its meaning for development of Republic of Macedonia] (Skopje: MANU, 2009), 171-202.
} 
lawyers and university professors who emphasized in their profession with their own scientific or professional work, or with public action. Additional condition is to have minimum 15 years of working experience or 12 years of experience if they hold a PhD title. ${ }^{23}$ By establishing concrete standards and definitions of what is a distinguished lawyer and what kind of experience the future constitutional judge should have, maybe we can not erase the political influence on this court completely, however, at least we can increase the reputation of the judges and the court itself and set standards that can guarantee full protection of the Constitution and the citizens' rights in future.

\section{POLITICAL INFLUENCE THROUGH THE DISSENTING OPINIONS IN THE MACEDONIAN CONSTITUTIONAL COURT IN THE PERIOD OF 2012-2015}

The ruling of the right-wing demo Christian political party VMRO-DPMNE in the period 2006-2016 was marked as one of the darkest periods in the Macedonian democracy. Not only was the level of corruption high, level 35 by the Transparency International ranking, but the state was hit by the wire-tapping scandal in which it was uncovered that the state secret police was unlawfully wire taping conversations of 20.000 citizens. ${ }^{24}$ When the opposing Social Democratic Party in 2015 started publishing certain wire-taped conversations, the public found out that not only were minimum 4 out of 8 elections since 2006 (presidential, local and parliamentary) fraud, but the former minister of interior attempted to hide a murder. Scandals, political pressure, threats and blackmail were quite common in the political scene in the decade which completely devastated the state institutions. The Constitutional Court was not exempt from those political games and maneuvers which in the given period inflicted enormous damage on the reputation of the court.

As mentioned in the beginning, the ruling political party, VMRO-DPMNE, has installed its judge as a president of the court, from retirement, Elena

23 "Croatian Constitutional Court," accessed 8 August.2018, https://www.usud.hr/.

24 "Annual Reports," Transparency International, accessed 2 August 2018, https://www.transparency.org/news/ feature/corruption_perceptions_index_2017. 
Gosheva as well as one more, Jovan Josifovski. The damaging policy of the former government will be analyzed through the published dissenting opinions of now former constitutional court, Natasha Gaber Damjanovska. Following the example of the Hungarian judge Imre Voros, she, as well, has published a book of her dissenting opinions from the period of her mandate as a constitutional judge (2009-2018), "In defense of the Constitution and civilization values." ${ }^{25}$ The edition in which her dissenting opinions are published keeps a track of the period 2012-2015 in which the damaging governmental policy reached its pick. The analysis of the dissenting opinion on the amendments on the Law on Abortion, Law on Civil Responsibility, Insult and Slander, Law on Financial Discipline and several other laws and governmental decisions and civic requests can give clearer and deeper picture on how one undemocratic regime, full of corruption and state incorporated criminal, can systematically ruin the state. The following chapters presents the dissenting opinions on challenged articles of the amendments on the Law on Abortion, requests on protection of freedom of public expression and challenged articles of the Law on Determination of the Condition for Limitation of Performing Public Function, access to documents and publication of cooperation with the authorities of state security. Her dissenting opinions can also be found in the Bulletin published on the Court's web site.

\subsection{Challenged Act: Articles of the Law on Abortion}

In the following chapter will be given an introduction, excerpts of the dissenting opinion and explanation about the case of challenged articles of the Law on abortion. This case in the modern Macedonian history is one of the most direct attempts of the government to limit the right of abortion, using tools of bureaucracy and diminishing the woman's personality as a free human being to freely bring decisions for her own body.

\subsubsection{Short Introduction of the Case Example}

With the amendments of the Law on Abortion in 2014, the government of the coalition of VMRO-DPMNE and DUI attempt to diminish the access to abortion

\footnotetext{
${ }_{25}$ Natasha Gaber-Damjanovska, In defense of the Constitution and civilization values, (Skopje, 2016), accessed 5 August 2018, www. scribd.com/people/documents/2996697.
} 
to women and without direct prohibition, to make the practice of this right of women more complicated. A group of civil organizations for protection of health, women's rights, sexually marginalized groups, the Helsinki Committee and a professor from the Faculty of Law in Skopje submitted initiative to the Constitutional Court for assessment of the constitutionality of the amendments of the Law. Unfortunately, the Constitutional Court with the decision brought on 08.10.2014 decided not to act upon the submitted initiative. The explanation of the Court, in summary, is that all of the challenged articles are in line with the Constitution.

\subsubsection{Dissenting Opinion on the Courts Decision upon the Challenged} Articles of the Law on Abortion, Decision Number 137/2013 08/10/2014

The respective articles on what the position of the Constitutional Court upon this inappropriate decision was will not be dealt with, but the decision will be explained through discussion on the dissenting opinion of the judge Gaber Damjanovska. It is needless to say that her vote and position were opposite to the decision of the Court. In her dissenting opinion, she explains her position in detail, article by article, in favor of the protection of women's right on safe abortion.

Excerpt of the dissenting opinion No. 1:

The Law, initially in Article 2, affirms the free will of the pregnant woman. ${ }^{26}$ However, part of the further legal provisions, in their legal entirety and mutual reciprocal action, is in contradiction to the initially declared principle. The whole process of approval of the termination of pregnancy creates clear and, at the same time, hidden obstacles which impose numerous formal conditions that a woman has to meet before she can have her pregnancy terminated; this imposes time limitation as well as psychological obstacles which need to be overcome or "skipped" in order for the pregnant woman to prevail in her initial decision. These legal and administrative preconditions when analyzed separately might not leave an impression that they represent an obstacle for realization of the this right, but analyzed collectively and in relation to one another, they create a disabling legal context placing the

Law on abortion, Article 2: Termination on pregnancy is special medical intervention on which woman can freely decide.Right for interruption on pregnancy can be limited only because of protection on health and life of the pregnant woman. Official Gazette of the Republic of Macedonia No.87/2013. 
woman in a race against time and deadlines so as to meet all legal conditions an finally exercise her right on abortion. ${ }^{27}$

The subtlety of the attempt of the former government to diminish the right on abortion can be seen from this excerpt of the opinion. One of the standards that a state must fulfill to be considered democratic is the right and free access to safe abortion for women. This attempt of the previous government has pushed back Republic of Macedonia directly into the dark age of humanity. One of the examples of the complexity of exercising the right on abortion was the amendment of Article 9. This article listed the documents that a woman must submit for her request for abortion to be approved. In addition to the submission of the required confirmation on the decision to undergo an abortion, as well as documentation of ultrasonographic examination, women were asked to submit confirmation of pregnancy from specialist gynecologist, confirmation of being informed of the possible advantages and risks that derive from pregnancy, confirmation of the public prosecutor that a criminal proceeding has been initiated, confirmation concerning certain illnesses from another doctor, confirmation from the central for social care. The whole process of collecting these documents pushes women in unequal position and cuts the time for the medical intervention short, which directly puts women's life in danger.

Excerpt of the dissenting opinion No. 2:

When a doctor has determined that the termination of pregnancy is not possible due to a medical condition the pregnant woman is suffering from, or that such termination might be threatening the life and health of the woman, or if more than ten weeks have passed from the conception, Article 7 provides that the doctor is obliged to refer the pregnant woman to a first degree commission for pregnancy termination. ${ }^{28}$ In addition to the obligation of the medical staff to refer the pregnant woman to a firstdegree commission, it is not clear why Article 9 again requires the woman to file a written request for termination of the pregnancy (evidently, there is a lack in the automatization of the procedure when it comes to this type of patients). In this case, again, the pregnant woman is obliged to submit all previously submitted documentation again. ${ }^{29}$

\footnotetext{
Natasha Gaber-Damjanovska, In defense of the Constitution and civilization values, (Skopje, 2016), accessed 5 August 2018, www.scribd.com/people/documents/2996697.

28 Article 7 of the Pregnancy Termination Law, Official Gazette of the Republic of Macedonia No. 87/2013.

29 Supra note $26,19$.
} 
The second excerpt of the dissenting opinion pictures the further complexity to exercise the right on abortion. The endless list of the documents is not required to be submitted once but twice during the abortion process. It is important to have in mind the several attempts of doctors and health commissions to force the woman to change her mind during this humiliating procedure. This is a direct attack on the independence and sovereignty of women to make decisions for their own lives and bodies.

Excerpt of the dissenting opinion No.3:

The Law states but does not provide for concrete urgent procedure when it comes for urgent cases. This is a serious overlook given that because of the administrative labyrinths and under threat of harsh financial penalties for the medical staff, it can come to tragic consequences. It is in my view that, given the intimacy and sensitivity of the question concerning termination of pregnancy as well the its impact on the health, the very absence of concrete and carefully standardized regulation results in limitation of the constitutionally guaranteed rights. As an illustration of a violation of a constitutional right and due to absence of appropriate legal procedure concerning health issues, I cite the decision of the Constructional Court of Slovenia on the subject U-I-127/o1. The Constitutional Court was on opinion that the challenged Law on Immunization was not in accord with the Constitution because it failed to provide for regulation of the procedure and of the individuals' right to determination of justified reasons for not taking the mandatory vaccines and because it did not provide for regulation of the responsibility of the state for the damages caused to such individuals. ${ }^{30}$

Excerpt of the dissenting opinion No. 4:

In the end, I would like to emphasize that during the procedure for assessment of the constitutionality of the challenged articles, the Court should have taken into account the international documents ratified in accordance with the Constitution, and which are part of our internal legal system and cannot be amended by law (Article 118 of the Constitution): the European Convention of Humans Rights, the Convention for Elimination of All Forms of Discrimination of Women, the Convention on the Rights of Individuals with Disability, the Convention on the Rights of the Child..$^{31}$ 
As can be seen from the excerpts of the dissenting opinion, the intrusion into the women right on abortion by the former government was on a level of humiliation and subtly attempt through administrative barriers to diminish the right on choice. The dissenting opinion on this case did not changed the official decision of the Constitution Court, but was seen as a dignified and bold step forward in the protection freedom of choice and free access to safe abortion by legal experts and the public in general in Macedonia.

\subsection{Challenged Act: Request for Protection of the Freedom of Public Expression}

Breaking of freedom of expression of journalists during the period of ruling of VMRO-DPMNE was unusual. The following case will put a light on the most violent breaking of freedom of expression that Macedonian journalists have experienced.

\subsubsection{Short Introduction of the Case Example}

One of the biggest scandals and violations of the freedom of expression during the ruling of the government of VMRO-DPMNE took place on the $24^{\text {th }}$ of December 2012. The draft of the state budget for year 2013 was on the agenda of the Parliament session. Due to the conflict between MP's of the opposition and the ruling coalition resulting from the violation of the procedure for adoption of the budget, this session was of big interest to the public. In one moment, the security of the Parliament started removing the journalists from of the Parliament gallery by force. During this situation, security used excessive force thus violating the journalists right to free reporting. The explanation by the president of the Parliament that they were removed from the press gallery due to security threats was unfounded.

The Association of Journalists in Macedonia reacted and submitted a complain to the Ministry of Internal Affairs, Sector for Internal Control, asking for the identity of the security guards who used excessive force and the identity of the person who gave the order for the security to act. In their response, the Ministry of Internal Affairs claimed that everything had been within the 
frames of the Law on the Parliament, Article 43. Contrary of this response, the Ombudsman found that in this case the right on freedom of expression and the right on information were violated.

A group of journalists who were removed from the Parliament by force filed a request to the Constitutional Court for protection of their freedom and rights in accordance with the Article 110 of the Constitution concerning the freedom of public expression. Upon deliberation on this request, the Constitutional Court found that the force removal of the journalist from the Parliament did not constitute a violation of their right on freedom of expression and information. Here, it should be pointed out that Article 43 of the Law on Parliament concerning security measures, on which the response of the Ministry of Internal Affairs and part of the decision of the Constitutional court were based, does not provide for the possibility for Parliament security to remove journalists by force.

\subsubsection{Dissenting Opinion on the Court's Decision on Denying the Request} for Protection of the Freedom and Rights of the Article 110 from the Constitution, Decision Number 27/2013, 16.04.2014

The judge Gaber Damjanovska expressed her disagreement with the decision of the Court stating that there was no violation of the journalists' right to public expression and free information. Her dissenting opinion explains that the Constitutional Court during its session and while deciding upon the request of the journalists, considered only one side of the whole case, the side of the Parliament and the Ministry of internal affairs.

Excerpt of the dissenting opinion No. 1:

The adopted decision clearly shows that the Court deliberated on the merits of the case thus finding the grounds to assess if the claimants have had their right to freedom of speech violated by a particular activity and in accordance with Article 110 of the Constitution of the Republic of Macedonia (Article 51 of the Rule of Procedure of the Court). I reckon that it is completely unacceptable that the decision was adopted based on solely trusting the statements and actions recounted in the submission of only one of the parties in this case, without conducting a public discussion for 
the purpose of evaluating and specifying the evidence in accordance with the Constitution, the principles of the European Convention of Human Rights and the jurisprudence of the European Court of Human Rights. ${ }^{2}$

The excerpt demonstrates that, in this case, the Court considered only one side and indirectly expressed bias in favor of the Parliament and the Ministry of Internal Affairs.

Excerpt of the dissenting opinion No.2:

It is a widely accepted standpoint that healthy democracy presumes indirect control not by the legislator and the judicial authorities only, but by the public and the media as well, who cherish the vitality of public debate. The freedom of accepting information and ideas covers the right to request, access and collect information via possible legal sources. This, of course, means that beside media and journalists who provide information for publishing, this freedom also encompasses the right of the public to be adequately informed especially when it comes to questions of public interest. In this regard, the European Court of Human Rights has a clear position that the states cannot put themselves between the provider and the recipient of information, because they have a right to come in direct contact at their own will. Journalists have a duty to transfer information and ideas on all questions of public interest in a manner which is in line with their obligations and responsibilities thus respecting the public's right to obtain such information. Otherwise, journalism would not be able to practice its role of a "public supervisor," critic, and guardian of progress and democracy. ${ }^{33}$

This comment of the judge clearly shows that the state (in this case Republic of Macedonia and its institutions) has come between the source of the information and the public. By cutting off and disabling the communication whilst throwing out the journalists from the Parliament, the government played the role of a bully and ultimate controller of the public opinion.

Excerpt of the dissenting opinion No. 3:

With the aim to establish the factual situation and conduct a valid assessment of the necessity for removal of the journalists from the gallery, it was necessary to clarify the reasons for the security of the Parliament to decide to remove the journalists from the gallery even though all incidents and unrest were physically isolated and far from the journalists. The assertion 
that this was done for the "safe of the journalists" is absurd since it was an obvious fact that they just set in their places, completely passive and without any activity participating in the events, but only observed, which is their legitimate right since this is part of their professional reporting activity. It is also a fact that the journalists did not contributed to the conflict situation in any manner (this is not denied in the missive of the Parliament either), did not violate the order in the building of the Parliament, did not have direct contact with the President of the Parliament, neither with the MPs, nor the events outside of the Parliament building. Considering this factual situation, aside from the absence of clarity regarding certain questions, it is clear that there was no "imperative necessity" contentious action to be undertaken, since the individuals present in the gallery, due to its physical detachment from the Parliamentary Hall, could not be directly involved into the events in the Parliament, neither to contribute to an incident of bigger proportions related to the ongoing events. It is also evidently that the journalists did not feel that their integrity was endangered, therefore did not ask for, nor expected protection. ${ }^{34}$

The black stain on the Macedonian democracy that happened in 24 of December 2012 has not been cleared yet. Beside the established facts and recommendations given by the Parliamentary Commission, which was established to investigate this incident, nobody from the security was found nor the name of the person who gave the order was published. This part of the political mosaic filled with political pressure and low standards among professionals, specially within the police, clearly expresses how much the Republic of Macedonia was devastated during the ruling of VMRO-DPMNE coalition.

It is valuable to mention that after this decision of the Constitutional Court, the journalist has filed a complaint to the European Court of Human Rights which sentence was that the Parliament and the security have violated the rights of expression of the journalists. The Court in the explanation of the decision have quote the dissenting opinion of the judge Gaber Damjanovska which is very rare in practice of the Court. ${ }^{35}$

34 Ibid., 29.

35 European Court of Human Rights, Case: Selmani and others against Republic of Macedonia, appeal number67259/14, accessed 10 August 2018, https://hudoc.echr.coe.int/eng\#\{\%22fulltext\%22:[\%22macedonia\%22],\%22appno\%22 :[\%2267259/14\%22],\%22documentcollectionid2\%22:[\%22CLIN\%22],\%22kpdate\%22:[\%222017-02-09To0:00:00. oZ\%22,\%222017-02-09To0:00:00.0Z\%22]\}. 


\subsection{Challenged Act: Articles of the Law on Determination of Condition for Limitation on Performing Public Function, Access to Documents and Publication of Cooperation with the Authorities of State Security}

Several socialist-communist states from the former Eastern block took a step in dealing with the past in form of opening the classified documents of the secret police. Republic of Macedonia took that path in with the act named Lustration act or Law on Lustration in 2012. Unfortunately, this act did not uncover the former collaborators with the secret police from the previous system, but it was used by VMRO-DPMNE for public embarrassment and discrediting of the political opponents.

\subsubsection{Short Introduction of the Case Example}

As a fore mentioned, the Republic of Macedonia was a republic and a federal unit within Yugoslavia in the period of 1945 to 1991. In 2012, the government of VMRO-DPMNE passed a law officially named as the Law on Determination of the Conditions for Limitation of Performing Public Functions, Access to Documents and Publication of Cooperation with the Authorities of State Security. This Law was colloquially known as the Law on lustration. The explanation of the legislator was that the basic aim of this Law is to prevent current and former politicians, who were cooperating with the secret police in the period when Macedonia was part of Yugoslavia, to perform public functions. However, this Law, enacted by the government of VMRO-DPMNE, was not used for purposes of lustration and so-called "cleaning" of the institutions of the residues of the old system, but for complete discreditation of the political opponents and public shaming. This practice of the former government encountered loud public reactions and complete disagreement with the whole process and aim of the Law. A group of citizens together with the Helsinki Committee submitted a request for challenging the constitutionality of several articles of the Law. The Constitutional Court, by adopting Decision number 111/2012, decided not to start assessment of the constitutionality of the challenged articles. It must be mentioned that the Constitutional Court was deciding upon requests concerning the same Law previously, when the challenged acts were abolished. This third and last decision of the Court is completely opposite to the previous ones. 


\subsubsection{Dissenting Opinion on the Court's Decision not to Start Assessment of the Constitutionality of the Challenged Articles of the Law on Determination of Condition for Limitation on Performing Public Function, Access to Documents and Publication of Cooperation with the Authorities of State Security}

Excerpt of the dissenting opinion No.1:

My position concerning the challenged articles is opposed and based on the previous practice and position of the Court of the Republic of Macedonia on this question (decision number 42/2008, 77/2008, 52/2011 and 76/2011), the Amicus Curiae opinion of the European Commission for Democracy through Law (Venice Commission) prepared specifically to address this challenged law upon a request from the Constitutional Court of the Republic of Macedonia, the Resolution No. 1096 from 1996 with the supporting Guidelines for its application and the Resolution No. 1481 from 2006 of the Council of Europe, European Convention on Human Rights and Fundamental Freedom as well as the Jurisprudence of the European Court for Human Rights. ${ }^{36}$

Contradictions in the decisions of the Court concerning the same Law are obvious. Given the fact that the Venice Commission already had already given an opinion on this Law, the decision not to start the assessment of the challenged articles directly contradicted the prior practice of the Court. An absurdity of the Law concerned the determination of the period that the process of lustration should cover. Considering that Macedonia had had a new Constitutional order since 1991, it was more than logical for the exact period of lustration to cover the time from 1944 to 1991. However, the new amendments were to extend the period until 2019, 10 years after the establishment of the Commission governed by the Law. With these blurry legal solutions, it was more than obvious that the Law will not succeed in its previous mission, but it will be used only for daily politics and dirty discrediting of political opponents.

Excerpt of the dissenting opinion No.2:

Article 3 lists the "individuals" covered by the Law [Law on Lustration] and includes the President of the state, MP's, some members of the executive and legislative authority, but also certain employees in commercial broadcasting

$\overline{36}$ Supra note 26,64 . 
companies, certain officials of political parties and religious groups or heads of organizations part of the civil sector which are named "organizations of public character," including some non-state related functions, for example, lawyers and individuals who have gained capital of more than 5\% from previous state-owned companies.

In its previous decisions, the Constitutional Court has established that the state cannot go beyond the individuals who are employed in state institutions and the ones who are on positions to make decisions thus being in position to violate human rights. The repeated expansion of the list results in interference of the state into the work of affected individuals and organizations who do not fall under the domain of state institutions. Thus, the state exceeds the constitutionally "guaranteed freedom of association to exercise and protect their political, economic, social, cultural and other rights and convictions." (Article 20 of the Constitution) and violates the "constitutional determination of separation of the church from the state (Amendment VIII). The state does not have authority to suggest the "lustration" conditions which are to be provided for individuals operating in private and semi-private organizations, neither can it impose conditions which could negatively impact the work of these organizations which are not part of the state domain. ${ }^{37}$

It is clear that the former government, through the state institutions and this Law, has attempt to expand the political battle in all possible sectors of the state. The labeling of the political opponents as collaborators with the secret police within the previous regime to gain some beneficial or material wealth, was the ultimate goal of VMRO-DPMNE.

Excerpt of the dissenting opinion No.3:

A further absurdity is that in addition to individuals owning over $5 \%$ of the capital of previously state-owned companies, the lustration process also includes, as indicated by paragraph 25, "individuals related them' including natural persons who are: in relation to them through marriage or adoption, children and parents, brothers and sisters, half-brothers and half-sisters, grandmothers, grandfathers and nephews and nieces, their twice removed kin, those who have continuously lived together for five 
years in a parent/guardian-child relationship, stepmother or a stepfather, adopted children, daughter in law, son in law and the couples' parents. It is clear that these explicitly listed categories of individuals, based only on the personal connections with the individuals who own more than $5 \%$ of the capital, do not have access to a public position and do not have the opportunity to directly endanger the public and state security or the rights and freedoms of others. This overwhelmingly wide scope of individuals on which the lustration process should be applied, having in mind that could literally involve anyone, including minors, has reached its absurd boundaries and produces a possibility for harsh voluntarism and directly violates the constitutionally guaranteed right on privacy. ${ }^{3}$

The attempt for lustration of political opponents, even the ones who were already deceased, failed. In the arena of this political battle, one of the losers was the Constitutional Court as well. By adopting a decision completely opposite of the Constitution and its previous practice, the Court lost its dignity and reputation. The judges appointed by the majority of MPs, who at the time were in favor of VMRO-DPMNE, were installed through the Parliament and responsible for the current reputation of the Constitutional Court. It can be argued that the dissenting opinion on the case of lustration will be of immeasurable value for future researchers and legislators and serve as an example of how the tool of lustration is not to be practiced. Moreover, it exemplifies the consequences of adopting a decision contrary to a Court's established practice resulting in additional destruction of a Court's reputation and derogation of its major role as a protector of the Constitution and citizens' rights.

\section{CONCLUSION}

As a young state, the Republic of Macedonia has passed through a rough period of a political regime during which all tools for political pressure were used by the ruling VMRO-DPMNE. From shameless appointing of new judges and a president of the Court directly from retirement, to contradictory decisions which the Court itself has directly renounced. The evident sort comings within the functioning of the Constitutional court must be rectified in order to prevent further political pressure and interference into the work of the Court. The model

38 $\quad$ bid., 66. 
is not perfect, but if there is a will and if we take into consideration that the Constitutional Court is a relatively young institution, it can be a subject to changes and improvements. There are already existing legal solutions which can be implemented to increase the integrity of the judges and the Court, to make amendments to the standards of appointing constitutional judges and to establish the values and conditions a judge has to hold.

The dissenting opinions paint a clear picture of the intrusion that the former government attempted to install and minimize women rights on abortion. Unfortunately, in this case, the Constitutional Court was the "partner in crime" to the former government. Furthermore, by adopting the decision to deny the protection of the rights on freedom of expression of the journalists, the Constitutional Court put another label of shame on its face. The trend of controversial decisions reached its pick when the decision concerning the challenged Articles of the Law on Lustration was adopted. However, the dissenting opinions of the former Constitutional judge Natasha Gaber Damjanovska have not only given deeper insight into how the Court ruled in favor of the interests of the former government, but also exemplified the legal tools that the same Court should have used so as to protect the Constitution and the citizens' rights. Every written piece of opinion, comment, disagreement, article that condemns the harmful governmental policy is an educational source for learning lessons about what to do to improve in the future and not repeat the same mistakes.

During the ruling period of VMRO-DPMNE (2006-2016), the public and the citizens saw the Constitutional Court as the last sanctuary from the corruption and criminal plaguing the state institutions. As illustrated by the cases discussed above, the Court has made mistakes which cannot be forgotten. The matter comprising the dissenting opinions and the uncovered shortcomings in the functioning of the Court may not be enough to enable the creation of a perfectly functioning Court, but they can at least help improve it and raise it to a respectable level and re-assume its role of the biggest protector of the Constitution, civil and human rights of its citizens. 
In order to minimize the damage and to start upgrading the system of the Constitutional Court, primarily, the standards and rules of appointment new judges have to be changed, to prevent appointing judges from retirement and with strong political affiliation. The dissenting opinions are valuable source for the rules and guidelines of the voting behavior of the judges and important legal tool which can be a warning sign that something is going wrong within the Constitutional Court. We have the base and the tools, now we only have to implement them.

\section{BIBLIOGRAPHY}

Bricker, Benjamin, "Breaking the Principle of Secrecy: An Examination of Judicial Dissent in the European Constitutional Courts" (April 2017). Law E Policy 39, no. 2, 170-191, 2017. https://ssrn.com/abstract $=2957933$.

Carter, Stephen L., "Scalia, Antonin Dissenting: A Fragment on Religion." Yale Law Journal 126, no. 6, April 2016. https://www.yalelawjournal.org/tribute/ scalia-j-dissenting-a-fragment-on-religion.

Chapter XIV of the Ordinances of Medina, in New compilation of the Laws of Spain, Volume II, Official Gazette of the State 350 (1976) (Chapter XIV of the Ordenanzas de Medina, in Novíssima r ecompilación de las leyes de España,Tomo II, Boletín Oficial del Estado 350 (1976). Accessed 12 July 2018. http://pares.mcu.es/ParesBusquedas2o/catalogo/description/184080.

Constitutional Court of Republic of Macedonia, "Short History." Accessed 8 August 2018. http://ustavensud.mk/?page_id=4603.

Constitutional Court of Republic of Macedonia. "Competencies of the Constitutional Court." Accessed 3 August 2018. http://ustavensud.mk/?page_ $\mathrm{id}=4597$.

Constitutional Court of Republic of Macedonia. "Rules of Procedure of the Court." Accessed 30 July 2018. http://ustavensud.mk/?page_id=4605.

Constitutional Court of Serbia. Accessed 30 July 2018. http://www.ustavni.sud.rs/. 
Constitutional Court of Croatia. Accessed 30 July 2018. www.usud.hr.

Duvnjak, Gordana. "Уставен суд нова фаза [Constitutional Court, new phase].” Link last active 30.04.2017. Utrinski.com.mk.

European Commission. “Commission Staff Working Document." Accessed 30 July 2018. https://ec.europa.eu/neighbourhood-enlargement/sites/near/files/ pdf/key_documents/2016/20161109_report_the_former_yugoslav_republic_ of_macedonia.pdf.

European Court of Human Rights, Case: Selmani and others against Republic of Macedonia, appeal number67259/14. Accessed 30 July 2018. https:// hudoc.echr.coe.int/eng\#\{\%22fulltext\%22:[\%22macedonia\%22],\%22appno\%2 2:[\%2267259/14\%22],\%22documentcollectionid2\%22:[\%22CLIN\%22],\%22kpd ate\%22:[\%222017-02-09Too:0o:0o.oZ\%22,\%222017-02-09Too:0o:oo.oZ\%22]\}.

Fabbrini, Federico. "Kelsen in Paris: France's constitutional reform and the introduction of a posteriori constitutional review of legislation." German Law Journal 9, no.10 (2008): 1297-1312. http://diana-n.iue. it:8o8o/bitstream/handle/1814/20483/Fabbrini_GLJ_Kelsen\%2oin\%2oParis. pdf? sequence $=2 \&$ isAllowed $=y$.

Gaber Damjanovska, Natasha. "In defense of the Constitution and civilization values". February 2016, Skopje, Republic of Macedonia. Accessed 5 August 2018. www.mcms.mk, www.scribd.com/people/documents/2996697.

Garoupa, Nuno, Gomez-Pomar,Fernando, Gremb, Veronica. "Judging under Political Pressure: An Empirical Analysis of Constitutional Review Voting in the Spanish Constitutional Court”, Illinois Law, Behavior and Social Science Research, Research Paper No. LBSS11-22, May, 2011, Electronic Paper Collection: http://papers.ssrn.com/pape.tar?abstract_id=.

Ginsburg, Tom, Garoupa, Nuno. "Building Reputation in Constitutional Courts: Political and Judicial Audiences”. 28 Arizona Journal of International and Comparative Law 539 (2011). https://chicagounbound.uchicago.edu/cgi/ viewcontent.cgi?article=2441\&context=journal_articles. 
Ginsburg, Hon. Ruth Bader “The Role of Dissenting Opinion”s. Minnesota Law Review. http://www.minnesotalawreview.org/articles/the-role-of-dissentingopinions/.

Jakab, András."Judicial reasoning in Constitutional Court - A European perspective." German Law Journal 2, no. 29 (2013): 1215-1278. https:// static1.squarespace.com/static/5633oad3e4bo733dccoc8495/t/56bra89af8baf 3f557170597/1454483611910/GLJ_Vol_14_No_o8_Jakab.pdf.

Kelemen, Katalin. "Dissenting opinions in Constitutional Courts." German Law Journal 14, no.o8 (2013): 9. https://static1.squarespace. com/static/5633oad3e4bo733dccoc8495/t/56bia9oof8baf3f55717o6 ba/1454483714236/GLJ_Vol_14_No_o8_Kelemen.pdf.

Laffranque, Julia. "Dissenting Opinion in the European Court of Justice. Estonia's Possible Contribution to the Democratisation of the European Union Juridical System.” Juridica International 14 (2004): 14-23. juridica.ee/ international_en.php?document=en/international/2004/1/75752.SUM.php>.

Lagi, Sara. "Hans Kelsen and the Austrian Constitutional Court (1918-1929)." i, Revista Co-herencia 9, no. 16 Enero - Junio 2012, 273-295. Medellín, Colombia (ISSN 1794-5887). http://www.scielo.org.co/pdf/cohe/v9nı6/vgnı6a1o.pdf.

Lazarus, David, “The Supreme Court's Excessive Secrecy: Why It Isn't Merited", Findlaw Legal News, Sept. 30,2004, http://writ.news.findlaw.com/ lazarus/20040930.html.

Nagel, Robert F. "Political Pressure and Judging in Constitutional Cases", 61 U. Colo. L. Rev. 685 (1990), available at http://scholar.law.colorado.edu/ articles/916.

Preshova, Denis, „Македонски Уставен (Не) патриотизам, [“Macedonian Constitutional (Un) Patriotism"], Политичка мисла бр. 35, Септември 2011, 41-48, Political thought 35, Sept 2011, 41-48. 
Preshova, Denis, Реформи на Уставниот суд или реформа на свеста? Реформа на институциите и нејзиното значење за развој на Република Македонија [Reforms of the Constitutional Court or reforms of consciousness? Reform of the institutions and its meaning for development of Republic of Macedonia]. Skopje: MANU, 2009, $171-202$.

Sevrieva, Marija. "Уставниот суд ги укина измените на законот за помилување [The Constitutional Court have abolished the amendments on the Law on pardon]." Akademik, March 16 2016. Accessed 10.08.2018. https://www. akademik.mk/ustavniot-sud-gi-ukina-izmenite-na-zakonot-za-pomiluvanjeso-nego-se-ogranichuvalo-ustavnoto-pravo-na-pretsedatelot-na-rm/

Sevrieva, Marija. “Објавени помилувањата [The abolition are published]." Akademik, March 13, 2016. Accessed 10 August 2018. https://www.akademik. mk/objaveni-pomiluvanjata-gruevski-mijalkov-crvenkovski-obviniteli-vo-sjo/.

Sweet, Alec Stone, Constitutional Courts and Parliamentary Democracy (Special Issue on Delegation) (2002). Faculty Scholarship Series. Paper 84. http:// digitalcommons.law.yale.edu/fss_papers/84.

The Constitutional Court of the Republic of Macedonia. "Short Biography of Dr. Natasha Gaber-Damjanovska." goo.gl/5cmijo.

Transparency International. “Annual Report.” Accessed 2 August 2018. https:// www.transparency.org/news/feature/corruption_perceptions_index_2017.

Venice Commission, "The Composition of Constitutional Courts, in Science and Technique of Democracy o.2opt.4.2." 1997. Accessed 2 August 2018 http:// www.venice.coe.int/webforms/documents/CDL-STD(1997)o20.aspx.

Vörös, Imre. Dixi et salvavi. különvélemények, Párhuzamos indokolások [Dixi et salvavi. Dissenting and concurring opinions]. (2000). 